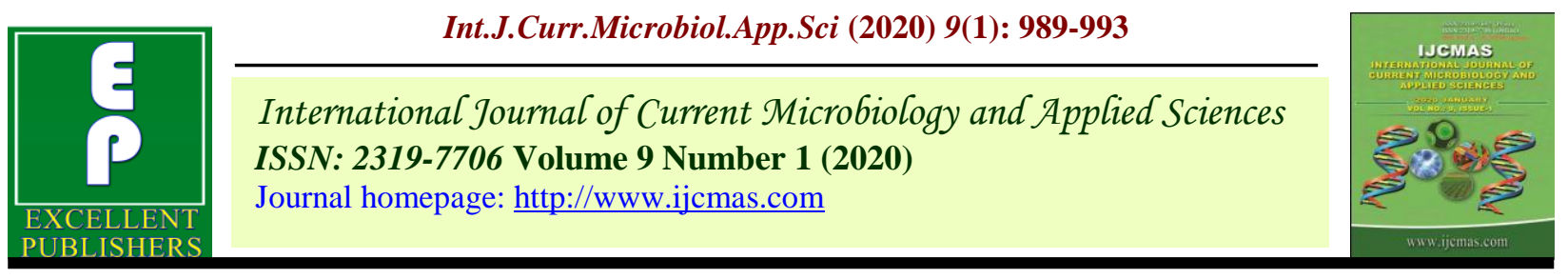

Original Research Article

https://doi.org/10.20546/ijcmas.2020.901.111

\title{
Effect of Plant Growth Regulators on Flowering and Quality of Tuberose (Polianthes tuberosa L.)
}

\author{
Y. R. Gawai ${ }^{1 *}$, Snehal Bayaskar ${ }^{2}$ and P. N. Davhale ${ }^{3}$ \\ Horticulture Section, College of Agriculture, Nagpur, India \\ *Corresponding author
}

A B S T R A C T

\begin{tabular}{|l|}
\hline Ke y w or d s \\
Tuberose, Plant \\
growth regulators, \\
Flowering and \\
quality
\end{tabular}

\begin{abstract}
An experimental study was carried out during kharif season of the year 2008-2009 at the farm of Horticulture Section, College of Agriculture, Nagpur. The experiment was laid out in Randomized Block Design (RBD) with three replications and ten treatments viz. $\mathrm{GA}_{3}$ at 100,150 and 200 ppm, NAA at 50, 100 and $150 \mathrm{ppm}, \mathrm{CCC}$ at 1000, 1500 and $2000 \mathrm{ppm}$ and control (Water spray). The higher concentration of $\mathrm{GA}_{3}$ at $200 \mathrm{ppm}$ attributed superior results regarding earliness in initiation of flower stalk, length of spike and length of rachis. The diameter of spike, length and diameter of fully opened florets, vase life of spike, found to be significantly maximum with $\mathrm{CCC}$ at $1500 \mathrm{ppm}$.
\end{abstract}

\section{Introduction}

Tuberose (Polianthes tuberosa L.) is one the dearest flower to the mankind among the ornamental bulbous plants. Tuberose is much adore for its colour, elegance and fragrance, it occupies a prime position because of its popularity as cut flowers, loose flowers as well as for its potential in perfume industry. Loose flowers are used for making artistic garlands, floral ornaments, bouquets and button holes etc. Tuberose is commercially propagated vegetatively by means of bulbs. It is a day neutral plant; it requires high humidity and $20-30^{\circ} \mathrm{C}$ temperature for its luxuriant growth. Tuberose (Polianthes tuberosa L.) belongs to family Amaryllidaceae, is native of Mexico. In India, it is popularly known as Rajanigandha, Nishigandha, Sugandharaja, Gulcheri, and Gul-eshahu. Tuberose is muchadorned for its colour, elegance and fragrance. Among the commercially grown flowers, Tuberose occupies prime position in India since it is used as cut flower, loose flower as well as for its potential in perfume industry. Tuberose is cultivated in many tropical and subtropical parts of world including India.

Plant growth regulators have significant role in modifying the growth and flowering of plant. Today, the practical use of growth 
regulating substances in horticulture has assumed invariable dimensions due to revealed capacity of many significant mechanisms in plant which have led to a situation nearly approaching to horticultural revolution (Devadanam et al., 2007 ${ }^{\mathrm{b}}$ ). Keeping in view the above points, the experiment was undertaken to study the effect of foliar application of plant growth regulators on growth, flowering and yield of tuberose.

\section{Materials and Methods}

The investigation was undertaken at the farm of Horticulture Section, College of Agriculture, Nagpur during kharif season of the year 2008-2009 in Randomized Block Design (RBD) with ten treatments replicated three time. Three growth regulators with three concentrations of each, i.e. $\mathrm{GA}_{3}(100,150$ and $200 \mathrm{ppm})$, NAA (50, 100 and $150 \mathrm{ppm})$ and CCC (1000, 1500 and $2000 \mathrm{ppm})$ along with a control (Water spray) were used to study the effect on growth, flowering and yield of tuberose.

The foliar sprays of growth regulators in the concentration as per treatments were undertaken once on dated $15^{\text {th }}$ June 2008. The experiment was super imposed on already established tuberose plot of cv. Single raised on flat beds at spacing of $20 \mathrm{~cm} \mathrm{x} 20 \mathrm{~cm}$ during the year 2007. Before conducting the experiment, water stress was given from $30^{\text {th }}$ April 2008 till the monsoon start. The recommended dose of chemical fertilizers at the rate of 200:300:200 kg NPK ha ${ }^{-1}$ along with FYM @15 t ha ${ }^{-1}$ was applied before start of experiment. The full dose of $\mathrm{P}_{2} \mathrm{O}_{5}$ and $\mathrm{K}_{2} \mathrm{O}$ along with $1 / 4^{\text {th }}$ dose of $\mathrm{N}$ as a basal was applied on dated $1^{\text {st }}$ June 2008 and remaining doses of $\mathrm{N}$ were given in three equal splits after 30, 60 and 90 days. . The various observations on flowering viz., days required for initiation of first flower were recorded after planting, length of spike, diameter of spike, length of rachis, length of florets, diameter of florets, vase life of spike were recorded after harvesting. Collected data were analyzed as per the method suggested by Gomez and Gomez (1984).

\section{Results and Discussion}

\section{Effect of plant growth regulators on flowering of tuberose}

The data regarding to the number of days required for initiation of first flower stalk (spike) was recorded and presented in Table-1 and it is revealed that the minimum days required for spike initiation ( 42.80 days) were recorded under the treatment $\mathrm{GA}_{3}$ at $200 \mathrm{ppm}$, which was significantly superior over all other treatments. It might be due to the early production of florigine in $\mathrm{GA}_{3}$ treated plant, as $\mathrm{GA}_{3}$ is a component of florigine that required for formation of flowers in the plant system. Similar results were obtained by Sanap et al., (2004) and Devadanam et al., $\left(2007^{\mathrm{b}}\right)$ in tuberose.

\section{Effect of plant growth regulators on quality of tuberose}

It is revealed from the data presented in Table-1 that foliar spray of different plant growth regulators had significant effect on flower quality parameters of tuberose plants. Significantly, maximum length of spike $(106.06 \mathrm{~cm})$ and length of rachis $(31.23 \mathrm{~cm})$ was observed under the treatment $\mathrm{GA}_{3} 200$ $\mathrm{ppm}$. The $\mathrm{GA}_{3}$ treatments produced maximum length of spike and length of rachis; it might be due to acceleration in cells elongation and cell division of flowering spike. The above results are in close agreement with the findings of Leena et al., (1992), Singh and Barad (2002) in gladiolus, Sagar et al., (2005) and Devadanam et al., $\left(2007^{\mathrm{b}}\right)$ in tuberose. 
Table.1 Effect of foliar application of plant growth regulators on flowering and quality of tuberose cv. Single

\begin{tabular}{|c|c|c|c|c|c|c|c|}
\hline Treatments (ppm) & $\begin{array}{c}\text { Days required for } \\
\text { initiation of first } \\
\text { flower stalk (Spike) }\end{array}$ & $\begin{array}{l}\text { Length of } \\
\text { spike (cm) }\end{array}$ & $\begin{array}{l}\text { Diameter of } \\
\text { spike }(\mathbf{m m})\end{array}$ & $\begin{array}{l}\text { Length of } \\
\text { rachis }(\mathrm{cm})\end{array}$ & $\begin{array}{c}\text { Length of } \\
\text { fully opened } \\
\text { florets (cm) }\end{array}$ & $\begin{array}{l}\text { Diameter of } \\
\text { fully opened } \\
\text { florets }(\mathrm{cm})\end{array}$ & $\begin{array}{l}\text { Vase life of } \\
\text { spike (days) }\end{array}$ \\
\hline $\mathrm{GA}_{3}-100$ ppm & 47.26 & 101.03 & 8.18 & 28.40 & 6.17 & 3.22 & 11.60 \\
\hline $\mathbf{G A}_{3}-150$ ppm & 45.73 & 102.96 & 8.40 & 29.53 & 6.38 & 3.40 & 12.26 \\
\hline $\mathrm{GA}_{3}-200$ ppm & 42.80 & 106.06 & 8.58 & 31.23 & 6.51 & 3.62 & 12.96 \\
\hline NAA - 50 ppm & 49.96 & 95.43 & 7.64 & 24.63 & 5.20 & 2.86 & 9.66 \\
\hline NAA - 100 ppm & 51.30 & 96.96 & 7.84 & 25.90 & 5.43 & 3.12 & 10.06 \\
\hline NAA - 150 ppm & 52.83 & 98.70 & 8.02 & 27.06 & 5.71 & 3.38 & 10.40 \\
\hline CCC - 1000 ppm & 55.66 & 91.56 & 8.72 & 21.56 & 6.73 & 3.89 & 14.06 \\
\hline CCC - 1500 ppm & 57.40 & 89.96 & 9.02 & 23.03 & 6.86 & 4.12 & 15.10 \\
\hline CCC - 2000 ppm & 58.70 & 87.90 & 8.45 & 24.23 & 6.57 & 3.68 & 13.13 \\
\hline Control (W.S.) & 60.63 & 93.66 & 7.17 & 19.90 & 4.97 & 2.48 & 7.93 \\
\hline $\mathrm{SE}(\mathrm{m}) \pm$ & 0.69 & 0.69 & 0.04 & 0.49 & 0.10 & 0.11 & 0.20 \\
\hline CD at $5 \%$ & 2.05 & 2.07 & 0.13 & 1.47 & 0.31 & 0.32 & 0.60 \\
\hline
\end{tabular}


In respect of diameter of spike, the data presented in Table-1 revealed that, maximum diameter of spike $(9.02 \mathrm{~mm})$ was recorded under the treatment CCC-1500 ppm, which was significantly superior over all other treatments under study. Cycocel (CCC) helps in formation of more food material i.e. carbohydrates and thereby resulted maximum diameter of spike. Similarly, Baskaran and Misra (2007) reported maximum diameter of spike in gladiolus.

It is evident from the data presented in Table1 that significantly, maximum length of fully opened florets $(6.86 \mathrm{~cm})$ and diameter of fully opened florets $(4.12 \mathrm{~cm})$ were recorded in the treatment CCC-1500 ppm. The increase in size of florets by the foliar application of CCC might be due to suppression of apical dominance, which attributed to increase mobilization of biomass to flowers from the source. Similar results were reported by Leena et al., (1992) in gladiolus, Sagar et al., (2005) in tuberose.

Similarly, maximum vase life of spike (15.10 days) was recorded in the treatment CCC$1500 \mathrm{ppm}$, which was significantly superior over rest of the treatments under study and the data presented in Table-1. Cycocel (CCC) in higher concentration was found more effective in prolonging vase life of flowering spike than $\mathrm{GA}_{3}$ and NAA application. Similar results were reported by Katkar et al., (2005) in china aster, Baskaran and Misra (2007) in gladiolus.

\section{References}

Baskaran, V, and R. L. Misra. 2007. Effect of plant growth regulators on growth and flowering of gladiolus. Indian J. Hort. 64(4): 479-482.

Biswas J., T. K. Bose and R.G. Maiti.1983. Effect of growth substances on growth and flowering of tuberose (Polianthes tuberosa L.). South Indian Hort. 31 (2/3): 129-132.

Devadanam, A., P. B.Sable, B. N. Shinde, and A. M. Haldewad. 2007 . Effect of foliar spray of plant growth regulators on growth and yield of tuberose (Polianthes tuberosa L.). J. Maharashtra agric. Univ. 32(2): 282-283.

Katkar, P. B., D. M. Naik, S. G. Bodamwad and S. N. Gharat. 2005. Influence of plant growth regulators on flowering, quality and yield of flowers in china aster (Callistephus chinesis (L.) Nees.) cv. California Giant Mix. South Indian Hort. 53(1-6): 378-381.

Leena, Ravidas, P. K. Rajeevan and P. K. Vasalakumari. 1992. Effect of foliar application of growth regulators on the growth, flowering and corm yield of gladiolus. cv. Friendship. South Indian Hort. 40(6): 329-335.

Reddy, B. S., K. Singh and P. M. Gangadharappa. 1997. Effect of growth substances on flowering and shelf life of flowers of tuberose cv. Double. Karnataka J. Agric. Sci. 10(3): 731-737.

Sagar, N. N., V. J. Kawarkhe, Manisha Deshmukh and B. S. Lokhande. 2005. Effect of preplanting growth regulator treatment of bulbs on growth and flowering of tuberose (Polianthes tuberosa L.) Orissa J. Hort. 33(1): 3942.

Sanap, P. B., B. A. Patil and P. V. Gondhali. 2004. Effect of growth regulators on growth and flowering of tuberose (Polianthes tuberosa L.) cv. Single Orissa J. Hort 32(2): 120-122.

Sharma, D. P., Yamini K. Chattar and N. Gupta. 2006. Effect of gibberellic acid on growth, flowering and corm yield in three cultivars of gladiolus. $\mathrm{J}$ Ornamental Hort. 9(2): 106-109.

Singh, A. K. 1999. Response of tuberose growth, flowering and bulb production to plant bio-regulators spraying. Prog. 
Hort. 31(3-4): 181-183.

Singh, J. and A. V. Barad.2002. Effect of plant growth regulators on growth and flowering of gladiolus cv. Friendship. Gujrat J. Applied Hort. 2(2): 70-74.
Tak, D. and C. L. Nagda. 2000. Effect of growth regulators on growth and flower yield of tuberose cv. Single Hort. Abst. 70(2): 1572.

\section{How to cite this article:}

Gawai, Y. R., Snehal Bayaskar and Davhale, P. N. 2020. Effect of Plant Growth Regulators on Flowering and Quality of Tuberose (Polianthes tuberosa L.). Int.J.Curr.Microbiol.App.Sci. 9(01): 989-993. doi: https://doi.org/10.20546/ijcmas.2020.901.111 